\title{
HUMAN CAPITAL EFFICIENCY AND FIRM PERFORMANCE: AN EMPIRICAL STUDY ON MALAYSIAN TECHNOLOGY INDUSTRY
}

\author{
Azlina Rahim*1, Ruhaya Atan ${ }^{2}$ and Amrizah Kamaluddin ${ }^{2}$ \\ Faculty of Accountancy, Universiti Teknologi MARA Melaka \\ Faculty of Accountancy, Universiti Teknologi MARA, Puncak Alam, Selangor ${ }^{2}$
}

\begin{abstract}
This study examined the relationship between human capital efficiency and firm's performance in Malaysian technology industry. Using accounting data, this study reviewed annual reports of all technology companies listed under Main Market and Ace Market of Bursa Malaysia in year 2009. The study applied Value Added Intellectual Coefficient (VAIC ${ }^{\mathrm{TM}}$ ) methodology developed by Ante Pulic to measure human capital efficiency. The results showed that there was not much difference in terms of human capital efficiency between the Main Market and Ace Market. Results from correlation analysis indicate that human capital efficiency has significant and positive relation with firm's performance. Findings from this study may be useful to companies' managers to make better decision pertaining to the proper deployment of their strategic asset, namely human capital.
\end{abstract}

Keywords: human capital efficiency, $\mathrm{VAIC}^{\mathrm{TM}}$, technology industry

\section{INTRODUCTION}

Human capital is the components that emerged from the concept of intellectual capital (Bontis et al., 2000; Tayles et al., 2007). Human capital is the most important asset that exists within a firm. It represents the human factor in an organisation where by combination of intelligence, skills, knowledge, aptitudes and expertise that gives the organisation its distinctive character which those traits contributing to production and profitability, thus improve organizational performance (Bontis et al., 2000 Tayles et al., 2007; Gazor et al., 2013). Additionally, Yusuf (2013) argued that the ability of a corporate organization to successfully implement business strategies solely depends on efficient use of intangibles asset, particularly human capital.

Efficiency in using resources plays an important role in determining the strength of the organization. Measuring human capital performance has become an essential issue for companies in today's business world since it may help them to get the right perspective on human capital. A proper performance measurement tool could provide the firms with the necessary information for creating an action plan in order to improve human capital contribution to the organizational success.

The Value Added Intellectual Coefficient (VAICTM) has been introduced by Ante Pulic which can be used to measure the efficiency of intellectual capital within a company. The introduction of these monetary intellectual capital measurement methods provides new opportunities for companies and their stakeholders. This is because it provides a concrete basis for comparing the intellectual capital of different companies (Kujansivu and Lonnqvist, 2005). 
Even though the term intellectual capital is widely used in recent times by the research community in the developed countries, there have been very few studies that have used emerging economies for evaluating the implications of intellectual capital for the industries. Therefore, it becomes necessary to understand whether this resource is being efficiently utilized by the industries in the emerging economy to their advantage in creating value over time (Kamath, 2007).

The aim of this study is to provide an empirical view of the present state of human capital (HC) in Malaysian technology companies for year 2009. This paper investigated the relationship between human capital efficiency and firm's performance.

There is not much literature on human capital efficiency especially in Malaysia. Most of the studies focusing on the intellectual capital performance which majority of the studies in Malaysia focus on the finance sector. This paper differs from other Malaysian studies since it uses a sample of specific industry i.e. technology industry. Therefore, it contributes in the selection of sample size. Furthermore, the study measures the utilization of human capital efficiency in both Main Market and Ace Market of Bursa Malaysia. Thus, the results from this study may benefits the government and accounting professional bodies for future regulatory impact especially in drawing up future guidelines and policies pertaining to human capital performance. Additionally, it may facilitate the accountants and managers of the companies for better allocation of resources in those organizations.

The remainder of this article is structured in the following manner. The next section reviews the empirical background of the issue addressed in this study, followed by data and methodology. Then, the results of the study. The final section presents the conclusion and implications of the study.

\section{LITERATURE REVIEW}

\section{Definition of human capital}

There have been many attempts made by the researchers to define human capital. Different authors give different interpretation of this concept. Even though the definitions differ from one to another, many definitions have offered general view of the human capital. The underlying concepts in these definitions include the notions that human capital is emphasis on the skills and knowledge of employees rather than on the physical assets of a company Muhammad (2009). Human capital definitions by various authors summarized in Table 1.

Table 1: Summary of HC definitions

\begin{tabular}{|c|c|}
\hline Authors & Definition of human capital \\
\hline $\begin{array}{l}\text { Edvinsson and } \\
\text { Malone (1997) }\end{array}$ & $\begin{array}{l}\text { The knowledge, expertise, innovative ideas and the capability of employees to solve problems in } \\
\text { the organization }\end{array}$ \\
\hline $\begin{array}{l}\text { Becker, Huselid and } \\
\text { Ulrich (2002) }\end{array}$ & The productive efforts of an organization's workforce \\
\hline $\begin{array}{l}\text { Fincham and } \\
\text { Roslender (2003) }\end{array}$ & It is the only property which generates value \\
\hline $\begin{array}{l}\text { Chen, Zhu and Zie } \\
\text { (2004) }\end{array}$ & No value can be generate without human capital \\
\hline Ting and Lean (2009) & $\begin{array}{l}\text { Human capital include innovation, capacity, creativity, know-how and previous experience, } \\
\text { teamwork capacity, employee flexibility, tolerance for ambiguity, motivation, satisfaction, } \\
\text { learning capacity, loyalty, formal training and education. }\end{array}$ \\
\hline Baron (2011) & $\begin{array}{l}\text { It comprises of knowledge, skills, abilities to develop and innovativeness possessed by the } \\
\text { employees of an organisation }\end{array}$ \\
\hline
\end{tabular}


Micah, Ofurum and The energies, skills, talents and knowledge of people which are, or which potentially can be applied Ihendinihu (2012) to the production of goods or rendering useful services

\section{The concept of Human Capital Efficiency (HCE)}

Value Added Intellectual Coefficient (VAIC ${ }^{\text {TM}}$ ) developed by Ante Pulic is an analytical tool for measuring the efficiency of intellectual capital within a company. It was designed to enable management, shareholders and other relevant stakeholders to efficiently monitor and evaluate the efficiency of firm's total resources and each major resource component. The model gives a new insight into how value creation efficiency in the company is measured and monitored using accounting based figures.

One of the VAICTM components is human capital efficiency (HCE). HCE measures the value added by the human resources of an organization (Kwarbai and Akinpelu, 2016). Many literatures have discussed the advantages of using the VAIC ${ }^{\text {TM }}$ methodology usefully (Chan, 2009; Chen et al., 2005; Firer and Williams, 2003; Goh, 2005; Mavridis, 2004; Tseng and Goo, 2005; William, 2000). The availability of these studies adds further credibility to the usage of this methodology.

According to these researchers, VAICTM produces quantifiable, objective and quantitative measurements without the requirement of any subjective grading and awarding of scores or scales. It aids further computation and statistical analysis of a large sample size that may run into thousands of data items collected over a period of time.

Furthermore, it uses relatively simple and straightforward procedures in the computation of the necessary indexes and coefficients, which may be simple to understand, especially for management and business people who are accustomed to traditional accounting information. These coefficients enable the management to visualize the value creation efficiency of resources in the company. The higher the coefficient, the better management utilizes the company's value creation potential.

Even though there are several measurement methodologies, the most suitable method to measure the intellectual capital efficiency and relate it to the value of the organization is VAIC ${ }^{\text {TM }}$ created by Pulic and classified under ROA group method (Jurczak, 2008). The introduction of these monetary intellectual capital measurement methods provides new opportunities for companies and their stakeholders. This is because it provides a concrete basis for comparing the intellectual capital of different companies (Kujansivu and Lonnqvist, 2007).

\section{Human Capital Efficiency and Firm Performance}

Previous studies have shown that there is a significant relationship between human capital efficiency and organizational performance (Goh, 2005; Makki et al, 2008; Ting and Lean, 2009; Ghosh and Mondal, 2009). According to Plink and Barning (2010) human capital positively affects organizational performance because it can generate significant value for companies and provide them with sustainable competitive advantage.

Basically, these study focus on the intellectual capital as a whole. Riahi-Belkaoui (2003) investigated the effect of intellectual capital on multinational firms in the US. The sample of this research included 84 firms. The results revealed that there is a significant positive relationship between intellectual capital and firm performance Firer and Williams (2003) 
studied the relationship between the efficiency of value added and corporate performance. The results of their study indicated that the relationship between the efficiency of intellectual capital and corporate performance is limited and mixed. Mavridis (2004) applied the same method to analyze the data from Japanese banks and confirmed the existence of significant performance differences among the various groups.

Tseng and Goo (2005) studied the relationship between intellectual capital and the firm market value and financial performance in Taiwan. The data were extracted from 500 Taiwanese firms. The results of this research showed that there is a significant positive relationship between intellectual capital and firms' market value.

Another study on intellectual capital performance was conducted by Shiu (2006) where she examined 80 annual reports from Taiwan listed technologies firms. Based on the 2003 annual reports, results showed that the VAIC has a significant positive correlation to profitability and market valuation.

Kamath (2007) also adapted the same model for measuring the value-based performance of the Indian banking sector for a period of five years from 2000 to 2004 . The study confirms the existence of vast differences in the performance of Indian banks. There is an evident bias in favour of the performance of foreign banks compared with domestic banks.

Ghosh and Mondal (2009) analyzed the relationship between intellectual capital and the performance of pharmaceutical and software companies in India. Based on 80 companies, they concluded that there is a significant positive relationship between intellectual capital and Profitability. On the other hand, there is no significant relationship with productivity.

Zéghal and Maaloul (2010) measured intellectual capital and its relationship with financial performance and market value of commercial and industrial companies in UK. The study used data from 37 multinational companies in Serbia from 2006 to 2008. The results of this study reveal that there is a significant positive relationship between intellectual capital and the financial and economic performance of these companies.

Only few study that focus on the human capital. Yusuf (2013) investigated the relationship between human capital efficiency and financial performance of Nigerian banks. The study concluded that efficient utilization of human capital does not have any significant impact on the return of equity of banks.

Parham and Heling (2015) studied the efficiency of human capital and its impact on the financial performance of Dutch production companies. The study revealed that there is positive relationship between human capital efficiency and all three corporate performance measures' namely return on asset, return on equity and employee productivity. The result shows a strongly significant relationship between human capital efficiency and employee productivity.

In Malaysia, one of the earliest study on intellectual capital performance was conducted by Goh (2005), where he measured the intellectual capital performance of commercial banks for the period 2001 to 2003 . The results found that, all banks have relatively higher human capital efficiency than structural and capital efficiencies. As expected, foreign banks are intellectually more efficient than the domestic banks. The results revealed that there were significant differences between rankings of bank according to efficiency and traditional accounting measures.Hazlina and Zubaidah (2008) examined the intellectual capital and performance for 
companies listed in the Bursa Malaysia Main Board for the year 2005-2006. They found significant positive relationship to firms' profitability. However, there is no significant relationship between intellectual capital value and firms' market valuation for companies listed in Main and Second Boards.

Nik Maheran and Md Khairu (2009) investigated the intellectual capital efficiency and its performance in Malaysian financial sector. The data were taken from 18 companies under financial sector for the year 2007.It was found that intellectual capital has significant and positive relationships with company's performance measured by profitability and Return on Assets.

Further, Ting and Lean (2009) studied the intellectual capital performance and its relationship with financial performance of financial institutions in Malaysia for the period 1997 to 2007. The study revealed that intellectual capital performance and Return on Assets are positively correlated among the finance sector.

The recent study in Malaysia was conducted by Tze et al. (2011) where they review the annual reports of Food and Beverage (F\&B) companies from 2008 to 2010. Those companies selected were under consumer sector listed in Bursa Malaysia. The findings indicated that the beverage companies have greater VAIC compared to food companies over the 3 years period.

As one of the emerging market in Asia, there is a practical need for Malaysia to determine the human capital efficiency and understand the impact of human capital efficiency on firms' performance. Thus, the firms will get to know the utilization of their resources, so that they can decide on their future resource allocation decisions.

\section{RESEARCH METHODOLOGY}

\section{Sample Selection and Data Collection}

The study examined the annual reports of all technology companies listed under Main Market and Ace Market of Bursa Malaysia in year 2009. The technology industry was selected because; these companies rely on intellectual capital in the operation of their business as compared to other traditional sector companies. The data from this study were extracted from the company's annual reports. Bontis (2003) mentioned that annual reports are considered as an important source of company information by external users such as stakeholders.

All the annual reports were downloaded from the Bursa Malaysia website. Based on Bursa Malaysia web site, there are a total of 93 companies listed under Technology industry. However, due to some missing data and negative value added, some companies were eliminated. Therefore, the final data consists of 19 companies from the Main market and 36 were from Ace market. The details were tabulated in Table 2.

Table 2: Descriptive analysis of the sample

\begin{tabular}{|c|c|c|c|c|}
\hline & & riginal data & & Final data \\
\hline & Frequency & Percentage & Frequency & Percentage \\
\hline Main market & 22 & 23.7 & 19 & 34.5 \\
\hline Ace market & 71 & 76.3 & 36 & 65.5 \\
\hline Total & 93 & 100 & 55 & 100 \\
\hline
\end{tabular}




\section{The VAIC ${ }^{\mathrm{TM}}$ model}

The VAIC ${ }^{\mathrm{TM}}$ model was selected to measure the intellectual capital efficiency and its components namely human capital efficiency, capital employed efficiency and structural capital efficiency. Human capital efficiency indicates the value added by human capital which is the main focus in this study. This method has been widely used by researchers (Chen et al., 2005; Kamath, 2007; Nazari \& Herremans, 2007; Chan, 2009; Ghosh \& Mondal, 2012). Therefore, the selection for this model in Malaysian context is justifiable. In fact, VAICTM provides a unique measurement that can be used for comparative analyses across various companies, time periods and industries, both internationally and locally (Ranjith, 2007).

\section{FINDINGS AND DISCUSSION}

\section{Descriptive studies}

Table 3 presents the mean, standard deviation, minimum and maximum values of all variables for the year 2009. The mean of HCE is 2.64 with a range from 1.01 to 10.08 . On average, the Malaysian technology companies created RM 2.64 for every one ringgit employed. This result is consistent with Kamath (2008) and Firer and William (2003).

Table 3: Descriptive statistics for selected variables

\begin{tabular}{|c|c|c|c|c|}
\hline Variable & Mean & $\begin{array}{c}\text { Std } \\
\text { ation }\end{array}$ & Minimum & Maximum \\
\hline $\mathrm{HCE}$ & 2.6411 & 2.04851 & 1.01 & 10.08 \\
\hline ROA & .0741 & .06459 & .00 & .22 \\
\hline
\end{tabular}

Based on the mean and std deviation, there is not much difference in the mean and std deviation of human capital efficiency between Main Market and Ace Market. Both markets were utilizing their human capital well. The detail statistics for each market was tabulated in Table 4.

Table 4: Comparison of mean between Main market and Ace market

\begin{tabular}{cllll} 
& & Mean & & Std. Deviation \\
& Main market & Ace market & Main market & Ace market \\
HCE & 2.7426 & 2.5875 & 2.12574 & 2.03517 \\
\hline
\end{tabular}

This result has been supported statistically by conducting the independent samples t-test. The test was conducted to compare means between Main market and Ace market. Based on the test of equality of variances (Levene's test), it shows that the variances of the variable that is HCE for the two groups are equal $(\mathrm{p}$-value $=0.995>0.05)$. Therefore, it indicates that there was no significant difference in HCE for Main market and Ace market. The result was tabulated in Table 5 .

Table 5: Independent sample test

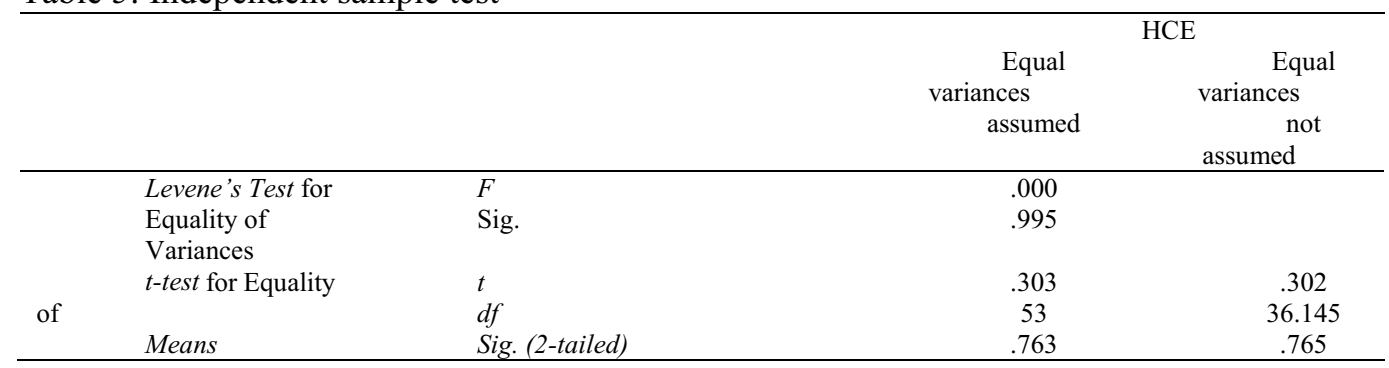




\begin{tabular}{lcc}
\hline Mean Differences & .19298 & .19298 \\
& & .63980 \\
Std. Error Difference & .63601 & \\
95\% Confidence Interval & & \\
of the difference & -1.08270 & -1.10442 \\
$\quad$ Lower & 1.46866 & 1.49038 \\
\hline
\end{tabular}

\section{Correlation Analysis}

The secondary data was checked for normality and the data was not normally distributed. Therefore, the non-parametric tests Spearman's rank-order correlation was applied to test the relationship between the variables. The findings indicate that $\operatorname{HCE}(r=0.539, \mathrm{p}<0.01)$ was significantly and positively correlated to ROA.

The correlation implies that human capital efficiency was significant factor in the technology industry; companies with higher human capital would be more profitable than others. Table 6 presents the results of the Spearman's correlations.

Table 6: Correlations (2-tailed)

\begin{tabular}{cl}
\hline & HCE \\
ROA & $0.539^{*}$ \\
\hline
\end{tabular}

Note: * indicates correlation is significant at the 0.01 level in the two-tailed test

\section{CONCLUSIONS AND IMPLICATIONS}

The purpose of this study is to provide an empirical view of the present state of human capital in Malaysian technology companies for year 2009. This study also measures the human capital efficiency and firm's performance in Malaysian technology industry. The data were extracted the annual reports of all technology companies listed under Main Market and Ace Market of Bursa Malaysia in year 2009.

The study reveals that the mean of HCE is 2.64 with a range from 1.01 to 10.08 . However, there is not much difference in the mean and std deviation of human capital efficiency between Main Market and Ace market in the technolgy industry. Spearman's rank-order correlation was applied to test the relationship between the variables. The empirical findings revealed that there is a significant positive relationship between HCE and ROA.

Findings from this study are subject to some limitations that provide initiatives for future research. The study was limited to one year sample. Therefore, the avenues for further research will include more data from more sample companies covering longer periods of time. In addition, it could be useful to further investigate the relationship of human capital and other firms' characteristics such as market value, return on investment and others.

In spite of some existing limitations, this study contributes to the human capital literature in several ways. First, human capital in a specific industry. Second, this study provides the empirical understanding on the human capital efficiency for both Malaysian markets; Main Market and Ace Market. Further, the study discuss in detail the human capital efficiency that been published in Malaysian annual reports. 
The results of this study may assist the companies to be more aware of other aspects of corporate reporting particulary on the human capital disclosure. In addition, it may benefit the regulators and standard setting bodies for future regulatory impact especially in setting framework for Malaysian companies.

\section{REFERENCES}

Abdul Latif, S. and Fauziah, S. (2007), "Intellectual capital management in Malaysian public listed companies', International Review of Business Resaerch paper, Vol 3, No 1, pp. 266- 278.

Becker, B., Huselid, M.A. \& Ulrich, D 2002 , Six key principles for measuring human capital performance in your organization, working paper

Baron, A. (2011). Measuring human capital. Strategic HR Review, 10(2), 30-35. doi:10.1108/14754391111108338

Bontis, N. William, C. and Richardson, S., (2000), "Intellectual capital and business performance in Malaysian industries", Journal of Intellectual Capital, Vol 1, No 1, pp 85-100.

Chen, J, Zhu, Z \& Xie, H 2004 'Measuring intellectual capital: a new model and empirical study', Journal of Intellectual Capital, Vol.5, No.1, pp. 195-212

Chan, K. H. (2009), "Impact of intellectual capital on organizational performance", The Learning Organization, Vol. 16, pp. 4-21.

Chen, M.-C., Cheng, S.-J., Hwang, Y. (2005), "An empirical investigation of the relationship between intellectual capital and firms' market value and financial performance", Journal of Intellectual Capital, Vol. 6 No.2, pp.159-76.

Damanpour F. (1991), "Organizational innovation: a meta-analysis of effects of determinants and moderators”, Academy of Management Journal, Vol 34, No 3, pp 550-90.

Edvinsson, L. (1997), "Measuring intellectual capital at Skandia", Long Range Planning, Vol. 30 No.3, pp.266-373.

Edvinsson, L., Malone, M.S. (1997), Intellectual Capital: Realizing Your Company's True Value by Finding Its Hidden Brainpower, Harper Business, New York, NY.

Fincham, R, Roslender, R (2003), 'Intellectual capital as management fashion: a review and critique', European Accounting Review, Vol.12,No.4, pp.781-795.

Firer, S and Stainbank, L. (2003), Testing the relationship between intellectual capital and a company's performance, Meditari Accountancy Research Vol. 11, pp 25-44

Firer, S. and Williams, S.M. (2003), "Intellectual capital and traditional measures of corporate performance”, Journal of Intellectual Capital, Vol. 4 No.3, 348-360. 
Goh, P.C. (2005), "Intellectual capital performance of commercial banks in Malaysia", Journal of Intellectual Capital, Vol. 6 No.3, pp.385-96.

Guthrie J. and Petty, R. (2000), “Intellectual Capital Literature Review: Measurement, reporting and management", The Journal of Intellectual Capital, Vol 1, pp155 - 176.

Ghosh, S. and Mondal A. (2009), "Indian software and pharmaceutical sector IC and financial performance”, Journal of Intellectual Capital, Vol. 6 No.3, pp.369-88.

Hazlina, H. and Zubaidah Z.A (2008), "Relationship between intellectual capital and firms' performance: evidence from public listed companies in Malaysia", Proceeding International Accounting Business Conference in Johor Bahru, Malaysia

Jurczak, J. (2008), "Intellectual Capital Measurement methods", Economics and Organization of Enterprise, Vol. 1, No.1, pp 37- 45

Kamath, B. G. (2007), "Intellectual capital performance of Indian banking sector", Journal of Intellectual Capital, Vol. 8 No. 1, pp96-123.

Kamath, B. G. (2008), "Intellectual capital and corporate performance in Indian pharmaceutical industry”, Journal of Intellectual Capital, Vol. 9 No. 4, pp 684-704..

Kaplan, R.S. and Norton, D.P. (2004), Strategy Maps: Converting Intangible Assets into Tangible Outcomes, Harvard Business School Press, Boston, MA.

Kujansivu, P. and Lonnqvist, A. (2005), "How do investments in intellectual capital create profits?", Frontiers of E-business Research, pp. 304-318.

Kujansivu, P. and Lonnqvist, A. (2007)." Investigating the value and efficiency of intellectual capital". Journal of Intellectual Capital, Vol. 8, pp. 272-287.

Lin, C. Y.-Y., \& Chen, M. Y.-C. (2007), „Does Innovation Lead to Performance? An Empirical Study of SMEs in Taiwan", Management Research News, Vol 30, No 2, pp 115132.

Lev, B. (2001), Intangibles: Management, Measurement, and Reporting, Brookings Institution Press, Washington, DC.

Luthy, D.H. (1998), "Intellectual capital and its measurement", Proceedings of the Asian Pacific Interdisciplinary Research in Accounting Conference (APIRA) Utah State University, Logan, Utah USA.

Mavridis, D.. (2004), "The intellectual capital performance of the Japanese banking sector", Journal of Intellectual Capital, Vol. 5 No.1, pp.92-115.

Mavridis, D. and Kyrmizoglou, P. (2005), "Intellectual capital performance drivers in the Greek banking sector", Management Research News, Patington, Vol. 28 No.5, pp.43-62. 
Micah L., Ofurum C., Ihendinihu J (2012), "Firms Financial Performance and Human Resource Accounting Disclosure in Nigeria", International Journal of Business and Management, Vol 7, No 14, pp 67-75

Montequin, V.R., Fernandez, F.O., Cabal,V.A., and Gutierrez, N.R. (2006), “An integrated framework for intellectual capital measurement and knowledge management implementation in small and medium-sized enterprises", Journal of Information Science, Vol 32,pp 525-538.

Nik Maheran N. M. and Md Khairu I. (2009) ."Intellectual Capital Efficiency and Firm's Performance: Study on Malaysian Financial Sectors", International Journal of Economics and Finance, Vol 1 No. 1, pp 206-212

Oke, A., Burke, G. and Myers, A. (2004). "Innovation types and their impact on performance in UK SMEs", The 11th proceeding. Cranfield School of Management, Cranfield University

Parham S. and Heling G. (2015), "The relationship between human capital efficiency and financial performance of Dutch production companies", Research Journal of Finance and Accounting; Vol. 6, No 8, pp. 188-201.

Pulic, A. (1998), "Measuring the performance of intellectual potential in knowledge economy”, available at: www.vaic-on.net (accessed 13 July 2009).

Pulic, A. (2001), "Value creation efficiency analysis of Croatian banks 1996-2000", available online at www.vaic-on.net (accessed 28 August 2009).

Pulic, A. (2004), "Intellectual capital - does it create or destroy value?", Measuring Business Excellence, Vol. 8 No.1, pp.62-8.

Ranjith, B. A. (2007),'The Impact of Intellectual Capital on Investors' Capital Gains on Shares: An Empirical Investigation of Thai Banking finance\& Insurance Sector", International Management Review; Vol. 3, No 2, pp. 14-25.

Riahi-Belkaoui, A. (2003), "Intellectual capital and firm performance of US multinational firms. A study of the resource-based and stakeholder views", Journal of Intellectual Capital, Vol 4,No 2, pp. 215-226.

Shiu, H. J. (2006), "The application of the value added intellectual coefficient to measure corporate performance: evidence from technological firms", International Journal of Management, Vol. 23 No. 2, pp. 356-365.

Schoenecker, T. and L. Swanson. (2002), "Indicators of firm technological capability: Validity and performance implications", IEEE Transactions on Engineering Management 49 (February): pp 36-44.

Sveiby, K.-E. (1997), The New Organizational Wealth: Managing and Measuring Knowledge-Based Assets, Berrett-Koehler Publishers Inc., San Francisco, CA .

Tan, H.P., David, H. and Hancock, P (2007). "Intellectual capital and financial returns of companies", Journal of Intellectual Capital, Vol 8, No. 1, pp 76-95. 
Ting, W.K. and Lean H. H. (2009), “ Intellectual capital performance of financial institutions in Malaysia”, Journal of Intellectual Capital, Vol 10 No 4, pp 588- 599.

Tseng, C. and Goo, J. (2005), "Intellectual capital and corporate value in an emerging economy: empirical study of Taiwanese manufacturers", R\&D Management, Vo. 35 No. 2, pp. 187-201.

Wang, W., Chang, Ch. (2005), "Intellectual capital and performance in causal models. Evidence from the information technology industry in Taiwan", Journal of Intellectual Capital, Vol 6., No. 2, pp. 222-236.

Yusuf I. (2013), "The relationship between human capital efficiency and financial performance: an empirical examination of quoted Nigerian banks", Research Journal of Finance and Accounting; Vol. 4, No 4, pp. 148-154. 